\title{
Farmers' Adoption of Rotational Woodlot (3) Technology in Kigorobya Sub-County of Hoima District, Western Uganda
}

\section{Research}

\section{Abstract}

This paper evaluates, using logistic and multiple regression analyses, the socio-economic factors that influence farmers' decisions to adopt rotational woodlot technology in the farming systems of Uganda, based on a household survey carried out between May and December 2004, involving 120 farmers in Kigorobya sub-county, Hoima district. The analyses demonstrate that farmers make decisions about woodlot technology based on the household and field characteristics. The factors that significantly influenced the decision to adopt rotational woodlot technology included: gender, tree tenure security, seed supply, contact with extension and research agencies, soil erosion index, size of landholding, fuelwood scarcity, and main source of family income. To promote greater adoption of rotational woodlot technology, particular attention should be placed on the use of appropriate socioeconomic characterization, to better target technologies to areas with greater adoption potential.

\section{Introduction}

Many regions in Africa are presently facing severe shortages of fuel wood, fodder and food primarily due to increasing human and livestock populations and crop production using little or no external inputs (FAO 2003). Farmers resort to using marginal and erosion-prone soils and to encroaching upon forests (Nyirenda et al. 2001). In most parts of sub-Saharan Africa, the traditional long duration fallows and shifting cultivation, which helps to replenish soil fertility to some extent, are no longer possible. Over the last two decades, woodlots have become popular among the development agencies in Africa as a means of improving fuelwood supply to rural communities and generating income for households (Jacovelli \& Caevalho 1999).
A rotational woodlot is a method involving growing trees with crops for two to three years until the trees start competing with the crops. Thereafter, the woodlot is left as a source of fuelwood, building poles or fodder while restoring soil fertility. Farmers then start cutting down the trees and growing crops between the stumps four to five years later (Nyadzi et al. 2003). Rotational woodlot technology involves growing trees and crops on farms in three inter-related phases: (i) An initial tree establishment phase in which trees are intercropped with crops; (ii) a tree fallow phase; and (iii) a cropping phase after harvesting the trees. Each of these phases can be managed specifically to provide products and services of economic, social and environmental value.

Some studies in developing countries have stressed a scarcity of fuelwood as one of the key factors to motivate farmers in adopting rotational woodlot technology (Jacovelli \& Caevalho 1999, Nyadzi et al. 2003). As long as fuel wood could be collected without paying for it, farmers had little incentive to plant fuelwood producing trees (FAO 2003). Nyadzi et al. (2003), however, reported that high fuel wood demand stimulates tree production, and that this is only the case when there is a fuel wood crisis. Thus, the high cost

\section{Correspondence}

M. Buyinza, Faculty of Forestry and Nature Conservation, Makerere University, P.O. Box 7062 Kampala, UGANDA buyinza@forest.mak.ac.ug

A.Y. Banana, G. Nabanoga, A. Ntakimanye, Faculty of Forestry and Nature Conservation, Makerere University, P.O. Box 7062 Kampala, UGANDA

Ethnobotany Research \& Applications 6:107-115 (2008) 
of fuel wood may motivate farmers to establish woodlots (Yin \& Hyde 2000).

Past studies (Masangano 1996, Omuregbee 1998) have identified some of the farmers' characteristics that may influence adoption of agroforestry technologies. These include the age, gender, and education level of the household head, wealth, family size, group membership and farm resources (such as farm size, land tenure, credit, or other inputs, and availability of labor). Farmers' adoption behavior, especially in low income countries is influenced by a complex set of socioeconomic, demographic, technical, institutional and bio-physical factors (Masangano 1996). This paper, therefore, evaluates the socioeconomic factors that influence farmers' decisions to adopt rotational woodlot technology in the farming systems in Kigorobya sub-county, Hoima district, western Uganda.

\section{Materials and Methods}

\section{Description of Study Area}

The study was conducted in Kigorobya sub-county, Hoima district between July and September 2005 . The district is located in mid-western Uganda (1 ${ }^{\circ} 00^{\prime}-2^{\circ} 00^{\prime} \mathrm{N}, 30^{\circ} 30^{\prime}$ - $\left.31^{\circ} 45^{\prime} \mathrm{E}\right)$. It is bordered by Lake Albert on the west, Kibaale on the south, Masindi to the northeast and Kiboga to the east). It has a population of about 341,700 people and a total area of 5,775 square kilometers. It lies at an altitude of $600-1000 \mathrm{~m}$ above sea level with undulating hills and predominantly savannah grasslands. The climate is characterized by small variations in temperature and humidity throughout the year. Mean annual rainfall ranges from $700-1000 \mathrm{~mm}$, most of which is received between October and April. Mean annual temperature is approximately $28^{\circ} \mathrm{C}$ with a range of $15-32^{\circ} \mathrm{C}$. Vegetation varies widely ranging from medium altitude moist forests through forest/savannah mosaic, swamp to post cultivation communities (Oluka-Akileng et al. 2000). The soils are mainly yellowish-red clay loams on sedimentary beds that occupy parts of Bugahya and Buhaguzi counties (Siriri \& Bekunda 2001).

Subsistence agriculture is the major economic activity, employing about $84 \%$ of the population (UBOS 2002). The bulk of the agricultural production is from manually cultivated rain-fed crops such as tobacco, cotton, sugarcane, and food crops. Typical food crops are maize, cassava and sweet potatoes. Kagorobya sub-county. was selected as a study site because it is economically backward with a subsistence economy. In each village there exists well documented secondary data on farmers that have adopted the woodlot technology (MWLE 2002).

\section{Data Collection}

Data for the study were collected through a cross sectional farm-level survey carried out between May and December 2004, by means of a structured questionnaire. The questionnaire was administered to 120 farmers to determine the profile of farmers' socio-economic variables and farm characteristics. The survey was done in two stages (Arkin \& Cotton 1963). In the first stage, focused group discussions were used to obtain background information on the adoption of rotational woodlot technology. This information was used to design a structured questionnaire administered to respondents during the second stage of the survey. Selection of the survey villages was accomplished through a stratified random sampling procedure. A complete list of villages where rotational woodlot technology has been previously introduced was available (FAO 2003).

Sample villages were selected based on the number of years of farmer exposure to woodlot technology, number of farmers exposed to woodlot technology, and an informed assessment by key informants on the extent of the adoption of rotational woodlot technology in each village. From each selected village, lists were developed of (a) all farmers who had been exposed to woodlot technology, and (b) those without such knowledge. A random sample was taken from each of the two groups of farmers. Descriptive statistics were used to describe the farmers' socio-economic characteristics, while simultaneous equation logistic models were employed to estimate the intensity of adoption (Maddala 1983). A series of explanatory variables included: gender of farmer, education level of farmer, family size, memberships to farmers' organizations, contact with extension agency, tree tenure security, fuel wood scarcity index, supply of planting materials, household source of income, and size of landholding (Table 1).

\section{Analytical Model}

A two-stage regression approach was adopted. In the first stage, a discrete variable logit assessment of the choice to adopt or not was carried out. In this case, a 100 percent sample was included in the model because it is a reasonable first choice for any farmer. The choice of the farmer to adopt woodlot technology or not was framed as a binarychoice model which assumed that individuals were faced with a choice between two alternatives and the choice depended on identifiable characteristics. The probability of adopting choice, $\operatorname{Pr}\left(T_{i}=1\right)$, was cumulative density function $F$ evaluated at $X_{i} \beta$, where $x_{i}$ is a vector of explanatory variables and $\beta$ an unknown parameter (Maddala 1983). This kind of cumulative density function can be modeled using logistic probability function, which has the following form: $x \beta$

$\begin{aligned} & \text { Choice to adopt } \\ & \text { rotational woodlot }\end{aligned}=\operatorname{PR}\left(T_{i}=1\right)=\frac{\exp \left(x_{i} \beta\right)}{1+\exp \left(X_{i} \beta\right)}$ 


\section{Buyinza et al. - Farmers' Adoption of Rotational Woodlot Technology in Kigorobya Sub-County of Hoima District, Western Uganda}

The Statistical Package for Social Scientists (SPSS VER. 11) program for Windows was used for the analysis. The estimated model was:

WOOD $=b_{0}+b_{1}($ GND $)+b_{2}(H S I Z)+b_{3}(E D U C)+b_{4}(E X T)+$ $b_{5}($ EROS $)+b_{6}\left(\right.$ FINC) $+b_{7}(F W D)+b_{8}($ TENUR $)+b_{9}($ ORG $)$

$+b_{10}($ LND $)+b_{11}($ SEED)

The qualitative dependent variable is woodlot technology (WOOD), which takes on the value of 1 if the farmer adopted woodlot technology and its variants, and 0 if no adoption occurred. Explanatory variables and justification are discussed below. Gender (GND) is a dummy variable that indexes the gender of the farmer; it has a value of 1 for men and 0 for women. It was hypothesized that GND is negatively related to the adoption of rotational woodlot technology. Size of household (HSIZ) measures the number of people living in the household. It is expected that the larger the number of members in the household the greater will be the availability of family labor for woodlot establishment and management. Farmer education (EDUC) measures the level of education of the farmer. It takes the value 1 , if no formal education; 2 , if completed primarily level; 3 , if completed secondary level; and 4 if University graduate. Education thus is expected to have a positive effect on the decision to adopt woodlot technology. Contact with extension (EXT) measures the contact of farmers with extension and research agencies that work on woodlot technology. It takes the value of 1 if the farmer had contacts with such agencies, and 0 , otherwise. It was hypothesized that EXT positively influenced decisions

Table 1. Farm household socioeconomic characteristics in Kigorobya sub-county, Hoima district, Uganda between July and September 2005. ( $=120)$.

\begin{tabular}{|l|c|}
\hline Variable & Percentage \\
\hline Adopters of rotational woodlot technology & 72 \\
\hline Farmers age & 43 \\
\hline$<18$ & 23 \\
\hline $19-29$ & 62 \\
\hline $30-39$ & 51 \\
\hline$=>40$ & 21 \\
\hline Education per family in schooling year \\
\hline 0 & 64 \\
\hline$<5$ & 15 \\
\hline$=>6$ & 03 \\
\hline Mean & \\
\hline Size of household members & 20 \\
\hline $1-4$ & 40 \\
\hline $5-7$ & 23 \\
\hline $8-10$ & 17 \\
\hline$=>10$ & \\
\hline
\end{tabular}

to establish woodlot of the farm field. Source of income (FINC) measures the farmer's main source of income and it takes the value 1 , if the main source is agriculture, and 0 if otherwise. Studies have shown that agriculture as the main source of income has a negative impact on the adoption of new agroforestry technologies (Adesina et al. 2000, Nyirenda et al. 2001). Fuelwood scarcity (FWD) indexes the extent of wood scarcity in the village where the farmer is located. It takes the value of 1 , if fuel wood is abundant in the village; 2 , if scarce and 3 , if very scarce. It is hypothesized that as the extent of fuel wood scarcity intensifies, farmers may have greater incentives to adopt woodlot technology.

In this study, soil erosion level (EROS) measures the extent of soil erosion in the village where the farmer is located. It takes on the value of 1 , if no erosion problem at all; 2 , if it is a minor problem; and 3 , if it is a severe problem. Tree tenure security (TENUR) indexes the security of tree rights on the private farm. It takes the value 1 if farmer has secure tenure rights and 0 otherwise. TENUR is positively related to adoption of woodlot technology. It is expected that if farmers have a complete bundle of rights, the likelihood of adopting rotational woodlot technology will increase. Membership to farmer organization (ORG) indicates if the farmer is a member of a farmers' association.

Membership to farmers' organization was hypothesized to positively influence the adoption of woodlot technology. Size of landholding (LND) is a dummy variable, which indexes whether the farmer has sufficient land. It takes the

\begin{tabular}{|c|c|}
\hline Variable & Percentage \\
\hline \multicolumn{2}{|c|}{ Amount of landholding } \\
\hline$<1$ ha & 32 \\
\hline $1-2$ & 32 \\
\hline $2.1-5$ & 22 \\
\hline$=>5$ & 14 \\
\hline \multicolumn{2}{|l|}{ Mean (2.4 ha) } \\
\hline \multicolumn{2}{|c|}{ Source of family income } \\
\hline Agriculture & 57 \\
\hline Non-agriculture & 43 \\
\hline \multicolumn{2}{|c|}{ Sources of information about woodlot technology } \\
\hline NAADS & 40 \\
\hline NGO & 23 \\
\hline Self experimentation & 02 \\
\hline Farmer to farmer & 33 \\
\hline Other sources & 02 \\
\hline \multicolumn{2}{|c|}{ Farmers aware of forestry extension activities } \\
\hline Aware & 27 \\
\hline Not aware & 73 \\
\hline
\end{tabular}


value of 1 if yes and 0 otherwise. It is expected that farmers owning big portions of land may face less pressure to establish woodlots on their own farms and this may negatively affect adoption of woodlot technology. Supply of planting material (SEED) measures the extent of availability of planting materials in the village. The seed supply takes the value 4, if National Tree Seed Center is the major source of planting materials; 3 , if own farm; 2 , if from open market; and 1 if it is from other sources.

Part of the taxonomical work was carried out at the Herbarium, Botany Department, Makerere University, Kampala, Uganda (MHU) where voucher specimens are deposited.

\section{Results}

\section{Field Survey Results}

The results presented in Table 1 show that average size of landholding in the area is 2.4 hectares of land. Approximately $64 \%$ of the households own less than 2 hectares and only $14 \%$ of the remaining households own over 5 hectares of land. Thus, a considerable number of farmers possessed a very limited amount of farm land to be used for production of household food and fuel wood. The median size of household members was 8 persons. Agriculture was the main source of income for approximately $57 \%$ of the households. Forty percent of the farmers reported that they obtained technical information on rotational woodlot technology from the National Agricultural Advisory Services, a program under the Ministry of Agriculture, and 23\% from non-government organizations in the area. Only $27 \%$ of the farmers were aware of the activities of the forestry extension programs. About $48 \%$ of the respondents mentioned natural regeneration as their source of seedlings, and a few farmers (4\%) acquired planting materials from the National Tree Seed Centre. The soil erosion index was rated high $(60 \%)$ and therefore many farmers planted trees on their private farm fields. Nearly all respondents $(99 \%)$ rely on biomass as a source of energy. Due to the general poverty in the rural areas, only $1 \%$ of the households can afford to purchase the commercial fuels such as electricity and petroleum products.

Table 2. Socio-economic and bio-physical field conditions in Kigorobya sub-county, Hoima district, Uganda between July and September 2005. 1US\$ = 1880 shillings (in 2005).

\begin{tabular}{|c|c|c|c|}
\hline Variable & Percentage & Variable & Percentage \\
\hline \multicolumn{2}{|l|}{ Source of seeds \& planting materials } & \multicolumn{2}{|l|}{ Soil erosion index } \\
\hline National Tree Seed Centre & 4 & High & 59 \\
\hline Natural regeneration & 48 & Low & 40 \\
\hline Market & 16 & \multicolumn{2}{|c|}{ Reasons for adopting rotational woodlot technology } \\
\hline Own nursery & 12 & \multirow{2}{*}{$\begin{array}{l}\text { Domestic consumption (Fuel wood, } \\
\text { construction materials, food) supply }\end{array}$} & \multirow[t]{2}{*}{68} \\
\hline Other farms & 20 & & \\
\hline \multicolumn{2}{|l|}{ Location of trees on farm } & Source of household income & 54 \\
\hline Homegarden & 27 & Social \& financial safe net & 38 \\
\hline Crop land & 07 & Soil conservation \& protection of & 42 \\
\hline Home compound & 50 & Eculugical Dalalice & \\
\hline Boundaries & 04 & Wind breaker & 18 \\
\hline Woodlots & 08 & Biodiversity and wildlife habitat & 05 \\
\hline Roadcide & 00 & Ornamental & 04 \\
\hline roauside & Uo & Others & 02 \\
\hline \multirow{2}{*}{\multicolumn{2}{|c|}{ Source of energy }} & \multicolumn{2}{|c|}{ Constraints to establishment of woodlots } \\
\hline & & Seedling supply & 20 \\
\hline Firewood & 93 & Lack of technical knowledge & 21 \\
\hline Charcoal & 03 & Land scarcity & $\frac{21}{23}$ \\
\hline Agricultural residues & 03 & Land \& tree tenure & 09 \\
\hline Commercial fuels & 01 & Culture and traditions constraints & 01 \\
\hline \multicolumn{2}{|l|}{ Distance in hours } & \multirow{2}{*}{ Lack of interest } & 10 \\
\hline$<1$ hour ( including on farm sources) & 80 & & 03 \\
\hline 1 - 3 hours & 18 & \multirow{2}{*}{$\begin{array}{l}\text { Others e.g diseases, competition with } \\
\text { food crops }\end{array}$} & \multirow{2}{*}{11} \\
\hline$>3$ hours & 02 & & \\
\hline
\end{tabular}




\section{Buyinza et al. - Farmers' Adoption of Rotational Woodlot Technology in Kigorobya Sub-County of Hoima District, Western Uganda}

\section{Empirical Model}

Binary logit coefficients (Table 1) showed that seven explanatory variables were significant in explaining farmers adoption of rotational woodlot technology. These were: tree tenure security (TENUR), seed supply (SEED), contact with extension and research agencies (EXT), soil erosion index (EROS), size of landholding (LND), fuel wood scarcity index (FWD), main source of family income (FINC) and gender of the farmer (GND).

Table 3. Binary logit model of the household characteristics influencing adoption of rotational woodlot technology in Kigorobya sub-county, Hoima district, Uganda between July and September 2005. Variables: gender (GND), farmer education (EDUC), household size (HSIZ), contact with extension (EXT), soil erosion level (EROS), source of income (FINC), fuelwood scarcity (FWD), tree tenure security (TENUR), membership to farmer organization (ORG), size of landholding (LND), and supply of planting material (SEED).

\begin{tabular}{|l|l|l|l|}
\hline Variable & $\begin{array}{l}\text { Coefficient } \\
\text { estimate }\end{array}$ & $\begin{array}{l}\text { Standard } \\
\text { error }\end{array}$ & p-value \\
\hline Constant & -9.869 & 3.855 & 0.0143 \\
\hline GND & 1.258 & 1.137 & $0.0926^{*}$ \\
\hline EDUC & 0.548 & 0.139 & 0.3706 \\
\hline HSIZ & -0.097 & 0.304 & 0.7503 \\
\hline EXT & 2.811 & 1.143 & $0.0139^{* *}$ \\
\hline EROS & -0.102 & 0.051 & $0.0442^{* *}$ \\
\hline FINC & -0.442 & 0.197 & $0.0202^{* *}$ \\
\hline FWD & -1.954 & 0.567 & $0.0006^{\text {** }}$ \\
\hline TENUR & 2.886 & 0.875 & $0.0009^{* * *}$ \\
\hline ORG & 7.071 & 9.466 & 0.4552 \\
\hline LND & -0.435 & 0.186 & $0.0242^{* *}$ \\
\hline SEED & 2.07 & 0.802 & $0.0011^{* * *}$ \\
\hline
\end{tabular}

Unrestricted Log likelihood function - 36.60; Restricted Log likelihood Function (-57.6); Degrees of freedom 45; Significance level (0.01) McFadden's R2 $=0.36$; Chi Squared (42.02). The asterixes: *, ${ }^{* *},{ }^{* * *}$ refer to significance at $\mathrm{P}=10 \%, 5 \%$, and $1 \%$ respectively.

\section{Trees and ShrubsGrown}

Trees commonly cultivated include Melia azedarach L., Markhamia lutea (Benth.) K. Schum., Vitellaria paradoxa C.F. Gaertn., Senna spectabilis (DC.) H.S. Irwin \& Barneby, Tamarindus indica L., Eucalyptus spp., Citrus spp., Mangifera indica L., and Sodom apple. There are also a number of trees planted as boundary marks and fences. These include: Ficus sp., Euphorbia spp., Cascabela thevetia (L.) Lippold, and Ejumukla. Some times trees are found scattered among crops in the field or, as seen on several occasions, beneficial trees are left stranding in the area; for example, Combretum spp., and Ficus spp. are often left scattered in cassava fields. This is a form of mixed intercropping where the tree component provides the environmental services and products to the household, whereas the annual crops provide the domestic food requirement. The tree products include fruits, vegetables, pods, seeds, firewood for energy provision, fodder for livestock. For example, Harrisonia abyssinica Oliv. and M. indica provide fodder to goats, sheep and cattle. Most of the indigenous tree species and shrubs are scattered in the fields or are found around courtyards, boundaries, and fences (Table 4).

Table 4. Trees and shrubs and their location in the farmer's fields in Kigorobya sub-county, Hoima district, Uganda between July and September 2005. Locations:B=Boundary, $\mathrm{C}=$ Courtyard, $\mathrm{H}=$ Home garden, $\mathrm{S}=$ Scattered.

\begin{tabular}{|c|c|c|c|c|}
\hline \multirow[t]{2}{*}{ Species } & \multicolumn{4}{|c|}{ Locations } \\
\hline & B & C & $\mathbf{H}$ & $\mathbf{S}$ \\
\hline Mangifera indica L. & & $X$ & & $\mathrm{X}$ \\
\hline Tamarindus indica L. & & & $\mathrm{X}$ & $\mathrm{X}$ \\
\hline Vitellaria paradoxa C.F. Gaertn. & & $\mathrm{X}$ & & $\mathrm{X}$ \\
\hline Albizia coriaria Welw. ex Oliv. & & & & $\mathrm{X}$ \\
\hline $\begin{array}{l}\text { Senna spectabilis (DC.) H.S. Irwin } \\
\text { \& Barneby }\end{array}$ & & & $\mathrm{X}$ & \\
\hline Melia azederach L. & & $\mathrm{X}$ & & \\
\hline Combretum spp. & & & & $\mathrm{X}$ \\
\hline Ficus dekdekena (Miq.) A. Rich. & & & & $\mathrm{X}$ \\
\hline Ficus glumosa Delile & & & & $x$ \\
\hline Ficus sycomorus L. & $\mathrm{X}$ & $X$ & & $x$ \\
\hline Erythrina abyssinica Lam. ex DC. & & & & $\mathrm{X}$ \\
\hline Acacia sieberiana DC. & & & & $\mathrm{X}$ \\
\hline Citrus spp. & & $\mathrm{X}$ & $\mathrm{X}$ & \\
\hline Vitex doniana Sweet & & & & $\mathrm{X}$ \\
\hline
\end{tabular}

The most practiced forms of agroforestry are seen to be home gardens and trees on cropland as well as planting trees on home compounds (50\%). However, many homes have one to four different species of trees on home compounds, used especially to provide shade in the dry season. Citrus species have been found to be the most favored and have been planted in most home gardens ( Table 5). This Citrus is used mainly as a source of food (fruit) and fire wood, as well as a source of income through the sale of the fruit.

None of the respondents planted trees on grazing land and public places. This is because farmers who keep livestock graze them on naturally growing pastures despite the fact that grazing land is dwindling, as reported by the respondents. No initiative or measure such as modern agroforestry has been taken to improve the quality and quantity of the palatable livestock pasture. However, there are some naturally growing indigenous trees like Acacia 
Table 5. Trees grown by the local community $(N=269)$ in Kigorobya sub-county, Hoima district, Uganda between July and September 2005.

\begin{tabular}{|c|c|c|}
\hline Species & Frequency & $\%$ \\
\hline Citrus spp & 36 & 13.4 \\
\hline Mangifera indica L. & 34 & 12.6 \\
\hline Emalaina & 21 & 7.8 \\
\hline Melia azederach L. & 21 & 7.8 \\
\hline $\begin{array}{l}\text { Senna spectabilis (DC.) } \\
\text { H.S. Irwin \& Barneby }\end{array}$ & 21 & 7.8 \\
\hline Carica papaya L. & 20 & 7.4 \\
\hline Anacardium occidentale L. & 14 & 5.2 \\
\hline Tamarindus indica L. & 13 & 4.8 \\
\hline Eucalyptus spp & 12 & 4.5 \\
\hline Passiflora edulis Sims & 12 & 4.5 \\
\hline Artocarpus heterophyllus Lam. & 7 & 2.6 \\
\hline $\begin{array}{l}\text { Markhamia lutea (Benth.) } \\
\text { K. Schum. }\end{array}$ & 7 & 2.6 \\
\hline Psidium guajava L. & 7 & 2.6 \\
\hline Ejumula & 5 & 1.9 \\
\hline Albizia coriaria Welw. ex Oliv. & 4 & 1.5 \\
\hline $\begin{array}{l}\text { Callitropsis Iusitanica (Mill.) } \\
\text { D.P. Little }\end{array}$ & 3 & 1.1 \\
\hline Cocos nucifera L. & 3 & 1.1 \\
\hline Milicia excelsa (Welw.) C.C. Berg & 3 & 1.1 \\
\hline Vitellaria paradoxa C.F. Gaertn. & 3 & 1.1 \\
\hline Cedrela odorata L. & 2 & 0.7 \\
\hline Eboboryei & 2 & 0.7 \\
\hline Ficus sur Forssk. & 2 & 0.7 \\
\hline Ficus sycomorus L. & 2 & 0.7 \\
\hline $\begin{array}{l}\text { Grevillea robusta A. Cunn. } \\
\text { ex } \mathrm{R} \text {. Br. }\end{array}$ & 2 & 0.7 \\
\hline Persea americana Mill. & 2 & 0.7 \\
\hline Pines & 2 & 0.7 \\
\hline Cascabela thevetia (L.) Lippold & 2 & 0.7 \\
\hline Combretum collinum Fresen. & 1 & 0.4 \\
\hline $\begin{array}{l}\text { Delonix regia (Bojer } \\
\text { ex Hook.) Raf. }\end{array}$ & 1 & 0.4 \\
\hline Jacaranda mimosifolia D. Don & 1 & 0.4 \\
\hline Kigelia africana (Lam.) Benth. & 1 & 0.4 \\
\hline $\begin{array}{l}\text { Musanga cecropioides R. Br. } \\
\text { ex Tedlie }\end{array}$ & 1 & 0.4 \\
\hline Syzygium Iusitanica Authority & 1 & 0.4 \\
\hline Vitex doniana Sweet & 1 & 0.4 \\
\hline
\end{tabular}

spp., Erythrina spp., Albizia spp., Vernonia spp., and Combretum spp. These play a big role in providing shade and improving the growth of pastures underneath.

Most farmers prefer planting fruit trees to planting non-fruit bearing trees. These trees serve a number of functions in the daily life of the people. The main uses as reported by the farmers are: Food, medicine, fuel wood, building poles, shade, windbreaks, source of income through the sale of firewood and/charcoal, soil fertility improvement and so on. Traditional furniture tree species are frequetnly used. These include: Maesopsis eminii Engl., Lovoa trichilioides Harms, Funtumia elastica (Preuss) Stapf, Entandrophragma angolense (Welw. ex C. DC.) C. DC. and Podocarpus latifolius (Thunb.) R.Br. ex Mirb. Non-traditional furniture tree species found in the area included Xylopia eminii Engl., Grevillea robusta A. Cunn. ex R.Br., Jacaranda mimosifolia D. Don, Artocarpus heterophyllus Lam., M. indica, Coffea robusta Linden and Ficus natalensis Hochst. (Table 6).

\section{Discussion}

The study revealed that farmers' adoption of rotational woodlot technology is influenced by the interacting farm household socio-economic characteristics such as gender of farmer, contact with extension and research agencies, soil erosion index, tree tenure security, seed supply, size of landholding, fuel wood scarcity index, and main source of family income.

Gender of the farmer was found to be significant and positively related to the adoption of woodlot technology. This suggests that men are more likely to establish woodlots on their fields than women. Adesina et al. (2000) argued that because rotational woodlot farming is primarily a treebased technology, women may be less likely to adopt it because of either lack of rights to grow trees or secure land rights. This may reflect the traditional bias against women in inheriting lands or having secure land or tree rights, or the inherent gender-bias in testing and demonstration of the technology. Masangano (1996) found that female farmers are less likely to use new technologies. Our field observations revealed that limitations on women in the decision making process and participation in forestry related matters further reinforces their limited access to forest resources.

The contribution of National Agricultural Advisory Services to encourage farmers to establish woodlots has been poor, and only $23 \%$ of the farmers have access to advisory services (Table 2). Thus, more widespread knowledge of the activities of the forestry extension programs could have a positive impact on farmers' decision to manage woodlots on their farm fields (Adesina et al. 2000, Nyirenda et al. 2001).

Our study supports the findings of Adesina et al. (2000), and Masangano (1996) that adoption of any innovation, 


\section{Buyinza et al. - Farmers' Adoption of Rotational Woodlot Technology in Kigorobya Sub-County of Hoima District, Western Uganda}

Table 6. Tree species found in Hoima district, Uganda between July and September $2005(\mathrm{~N}=60)$.

\begin{tabular}{|c|c|c|c|}
\hline Local Name & Botanical name & $\begin{array}{l}\text { Traditional } \\
\text { furniture tree } \\
\text { species) }\end{array}$ & $\begin{array}{l}\text { Non-traditional } \\
\text { furniture tree } \\
\text { species }\end{array}$ \\
\hline Mugavu & Albizia coriaria Welw. ex Oliv. & $\sqrt{ }$ & \\
\hline Nongo & Albizia gummifera (J.F. Gmel.) C.A. Sm. & & $\sqrt{ }$ \\
\hline Kirundu & Antiaris toxicaria Lesch. & $\sqrt{ }$ & \\
\hline Ffene & Artocarpus heterophyllus Lam. & & $\sqrt{ }$ \\
\hline Mwasa & Beilschmiedia ugandensis Rendle & & $\sqrt{ }$ \\
\hline Nkuzanyana & Blighia unijugata Baker & $\sqrt{ }$ & \\
\hline Cyprus & Callitropsis lusitanica (Mill.) D.P. Little & $\sqrt{ }$ & \\
\hline Muwafu & Canarium schweinfurthii Engl. & & $\sqrt{ }$ \\
\hline Nkalati & Chrysophyllum albidum G. Don & & $\sqrt{ }$ \\
\hline Mumwanyi & Coffea robusta Linden & & $\sqrt{ }$ \\
\hline Mukebu & Cordia millenii Baker & $\sqrt{ }$ & \\
\hline Mukusu & Entandophragma angolense (Welw. ex C.DC.) C.DC. & $\sqrt{ }$ & \\
\hline Kalitunsi & Eucalyptus grandis W. Hill ex Maiden & $\sqrt{ }$ & \\
\hline Mutuba & Ficus natalensis Hochst. & & $\sqrt{ }$ \\
\hline Katoma & Ficus sp & & $\sqrt{ }$ \\
\hline Nkago & Funtumia elastica (Preuss) Stapf & $\sqrt{ }$ & \\
\hline Greveria & Grevillea robusta A. Cunn. ex R. Br. & & $\sqrt{ }$ \\
\hline Mugu & Harungana madagascariensis Lam. ex Poir. & & $\sqrt{ }$ \\
\hline Jacaranda & Jacaranda mimosifolia D. Don & & $\sqrt{ }$ \\
\hline Mahogany & Khaya anthotheca (Welw.) C.DC. & $\sqrt{ }$ & \\
\hline Munyama & Khaya grandifoliola C.DC. & $\sqrt{ }$ & \\
\hline Nkoba & Lovoa trichilioides Harms & $\sqrt{ }$ & \\
\hline Musizi & Maesopsis eminii Engl. & $\sqrt{ }$ & \\
\hline Muyembe & Mangifera indica L. & & $\sqrt{ }$ \\
\hline Nkunya & Manilkara cuneifolia (Baker) Dubard & & $\sqrt{ }$ \\
\hline Musambya & Markhamia lutea (Benth.) K. Schum. & $\sqrt{ }$ & \\
\hline Mvule & Milicia excelsa (Welw.) C.C. Berg & $\sqrt{ }$ & \\
\hline Mpewere & Newtonia buchananii (Baker f.) G.C.C. Gilbert \& Boutique & $\sqrt{ }$ & \\
\hline Pine & Pinus caribaea Morelet & $\sqrt{ }$ & \\
\hline Podo & Podocarpus latifolius (Thunb.) R.Br. ex Mirb. & & $\sqrt{ }$ \\
\hline Settaala & Polyscias fulva (Hiern) Harms & $\sqrt{ }$ & \\
\hline Munaba & Pycnanthus angolensis (Welw.) Warb. & & $\sqrt{ }$ \\
\hline Musasa & Sapium ellipticum (Hochst.) Pax & & $\sqrt{ }$ \\
\hline Sekoba & Trichilia dregeana Sond. & & $\sqrt{ }$ \\
\hline Muyovu & Uapaca guineensis Müll. Arg. & & $\sqrt{ }$ \\
\hline Nsagalanyi & Xylopia eminii Engl. & & $\sqrt{ }$ \\
\hline
\end{tabular}


technology or agricultural practice will be accelerated if farmers have an accurate understanding of the principles underpinning extension recommendations. At the policy level, this implies that improving the quality of the National Agricultural Advisory Services system is of paramount importance in Uganda (Buyinza 2002).

For sustainability of the adoption of woodlot technology, a sustainable supply of planting materials in the form of seeds and seedlings is one of the pre-requisites. The majority of farmers interviewed depend on natural regeneration $(48 \%)$ and the open market as sources of planting materials (Table 2). Currently, the National Tree Seed Centre is not popular among farmers, and only $4 \%$ of the farmers interviewed obtained seeds from tree seed center. Farmer preferred to collect seedlings from their own superior trees $(12 \%)$ or from neighbors within the village. These results concur with those of Nyadzi et al. (2003) who reported that rotational woodlot technology depends on a reliable supply of quality planting materials.

The positive and significant sign on FWD implied that farmers in villages facing increasing fuelwood scarcities were more likely to adopt woodlot technology. Adesina et al. (2000) found that most of the fuel wood consumed by the farm households in forest margins of southwest Cameroon come from their food crop fields. Incidentally, it's within food crop fields that farmers establish woodlots. Woody perennial trees used in woodlots can further help farmers to increase the supply of fuel wood from their food crop fields (Buyinza 2002). Since farmers in villages with fuel wood scarcity were found to have higher likelihood of establishing woodlots, development efforts should target such villages, provided the level of fuel wood scarcity is not very serious. If it were, wood lots would be more appropriate in these areas. Since, tree farming requires that farmers set aside a part of their land for growing trees, the cultivatable area for food crops have to be reduced.

The farmers that have big landholdings are less likely to adopt woodlot farming. Farmers in villages where land is scarce are less likely to adopt woodlot farming because of the belief that trees will compete with the food crops. Wood fuel accounts for about $90 \%$ of energy used in Uganda (Falkenberg \& Sepp 1999). Growing trees as woodlots on farms in rotation with crops is considered a potential technology to overcome the shortage of wood, which is a common problem to many parts of Uganda (Jacovelli \& Caevalho 1999).

The fact that woodlot farming requires farmers to set aside part of their land for growing trees, results in the cultivable area under food crops being reduced. Farmers with smaller plots of land may view tree planting as competing with food crops, thus reducing incentives to establish woodlots. Nyadzi et al. (2003), reported that farmers in villages facing high land pressure may lack enough land for experimentation with agroforestry technologies. Since land availability is an important factor that determines development of each of the components in the woodlot farming system, variation in the size of holding affects the tree cropping intensity.

Farmers motivated to plant trees are faced with a shortage of available labour for food crop production (Adesina et al. 2000). Thus farmers whose main source of income is agriculture might be discouraged to allocate family labor for woodlots activities. About $10 \%$ of the farmers reported that a shortage of labour and capital to allocate for woodlot activities was a constraint to woodlot practices (Table 3 ). Trees provide at least $96 \%$ of the energy requirements in the study village (Table 2). Jacovelli \& Caevalho (1999) reported that in Uganda, biomass fuel is the principal energy source for household needs and about $52 \%$ of the biomass fuel comes from trees.

The farmers adopted woodlot technology mainly to provide for domestic consumption requirements such as firewood, construction materials (68\%) and source of household income (54\%). About $42 \%$ of the farmers interviewed reported that they had established woodlots as a financial security measure during declining revenues from the current marketable food crops. It has been shown (Falkenberg \& Sepp 1999) that fuel wood demand is an important factor in the inducement to plant trees.

In conclusion, this study has shown that the household and farm-level characteristics of gender, size of landholding, fuel wood scarcity, main source of family income, tree tenure security, reliable seed supply, contact with extension and research agencies, and soil erosion index of village impact the adoption of rotational woodlot technology.

\section{Acknowledgements}

This paper is an output of a community forestry field attachment supplemented with data from a special research project funded by the government of Republic of Uganda and Faculty of Forestry and Nature Conservation, Makerere University. The authors are grateful to the farmers who participated in the survey.

\section{References}

Arkin, H. \& R. Colton. 1963. Table for Statistics. Barnes and Noble Publisher, New York.

Adesina, A.A., D. Mbila, G.B. Nkamleu \& D. Endamana. 2000. Econometric analysis of the determinants of adoption of alley farming by farmers in the forest zone of southwest Cameroon. Agriculture, Ecosystems \& Environment 80:255-265. 


\section{Buyinza et al. - Farmers' Adoption of Rotational Woodlot Technology in Kigorobya Sub-County of Hoima District, Western Uganda}

Buyinza, M. 2002. Forestry Work in Villages: A guide for field workers. Makerere University. Fountain Publishers, Kampala, Uganda.

Buyinza M., M. Bukenya \& M. Nabalegwa. 2006. Financial efficiency of improved fallow agroforestry technology for bean production in Kakoonge Sub-county, Nakasongola District, Uganda. Uganda Journal of Agricultural Sciences, 12(1):45-56.

Falkenberg, C.M. \& S. Sepp. 1999. Economic evaluation of the forest sector in Uganda. Forest Sector Review. Ministry of Water, Lands and Environment, Kampala, Uganda.

Food and Agriculture Organization (FAO). 2003. Guidelines for Wood Energy Surveys. Food and Agriculture Organization of the United Nations, Rome.

Franzel, S., R. Coe, P. Cooper, F. Place \& S.J. Scherr. 2001. Assessing the adoption potential of agroforestry practices in sub-Saharan Africa. Agricultural Systems 69:37-62.

Jacovelli, P. \& J. Caevalho. 1999. The private forest sector in Uganda - opportunities for greater involvement. Forest Sector Review. Ministry of Water, Lands and Environment, Kampala, Uganda.

Maddala, G.S. 1983. Limited dependent and qualitative variables in econometrics. Economic Society Monographs 3. Cambridge University Press, London.

Masangano, C. 1996. Diffusion of Agroforestry Technologies [accessed 10 June 2004]. www.msu.edu/user/ masangn/agrof.html.
MWLE. 2002. The Uganda Forest Policy 2002. Ministry of Water, Lands and Environment, Kampala, Uganda.

Nyadzi, G.I., R.M. Otsyina, F.M. Banzi, S.S. Bakengesa, B.M. Gama, L. Mbwambo \& D. Asenga. 2003. Rotational woodlot technology in northwestern Tanzania: Tree species and crop performance. Agroforestry Systems 59:253263.

Nyirenda, M., G. Kanyama-Phiri, A. Bohringer \& C. Haule. 2001. Economic performance of improved fallow agroforestry technology for smallholder maize production in Central Malawi. African Crop Science 5:638-687.

Oluka-Akileng, I., J.F. Esegu, A. Kaudia \& A. Lwakuba. 2000. Agroforestry Handbook for the Banana-Coffee Zone of Uganda: Farmers' practices and experiences. Technical Handbook No. 21. RELMA/SIDA, ICRAF, Kenya.

Omuregbee, F.E. 1998. Communication of improved farm practices to rural women farmers in Benue State, Nigeria. Outlook on Agriculture 27:53-56.

Ramadhani, T., R. Otsyina \& S. Franzel. 2002. Improving household incomes and reducing deforestation using rotational woodlots in Tabora district, Tanzania. Agriculture, Ecosystems and Environment 89:229-239.

Siriri, D. \& M.A. Bekunda. 2001. Soil Fertility Management in Uganda: The potential of agroforestry. Agroforestry Research Network (AFRENA), Kabale, Uganda.

UBOS. 2002. Provisional Population Census Results. Uganda Bureau of Statistics, Entebbe, Uganda.

Yin, R. \& W.F. Hyde 2000. Trees as an agriculture sustaining activity: The case of Northern China. Agroforestry Systems 50:179-194. 
